\title{
Writing to Host Nationals as Cross-Cultural Collaborative Learning in Study Abroad
}

Le e a n n Ch e n

Embry-Riddle Aeronautical University

\section{Introduction}

Unlike education in the home country, where academic life generally separates itself from other aspects of students' lives, study abroad opens up the classroom to the whole society. Students' learning about cultural differences occurs, to a large extent, in their leisure time and in serendipity: with host families, in dorms shared with host-country students, in restaurants, parks, on the streets, and so on. All these out-of-classroom aspects are where ambiguity starts. Many students find study abroad appealing exactly because these aspects resemble vacationing (Altschuler). Thus, in the context of study abroad, traditional classroom education, independent of students' experiences, falls short of guiding students to reach their learning potential. Experiential education, by contrast, rests on drawing students' daily experiences into a "process" of "collective" learning (Carver 8-9). Such pedagogy answers the unique challenges of teaching study abroad courses.

What specific methods have study-abroad instructors been using to carry out experiential education? One of the most common seems to be writing, defined in this article as non-private journals and essays, in order to provide students with a process of discovery and learning. To name a few, Mildred Sikkema and Agnes Niyekawa's Design for Cross-Cultural Learning centers on journal writing. "Spanish Culture and Civilization," a course taught in Spain by an American instructor, requires students to write about their "cultural observations" and turn in the writing weekly 
for class discussion (Talburt and Stewart 4-5). So do Professor Ghislaine Geloin's French culture course in Nantes (Geloin), and Professor Donald Vanouse's course “Contemporary British Writers” in London (Vanouse). Indeed, with a relatively informal format, journals, as well as essays, invite students to reflect frequently on and make sense of their serendipitous experience. Furthermore, writing functions as a tangible record of students' learning outcomes. This essay is thus written for study-abroad instructors and directors who have been or who are interested in using writing as an effective structure of experiential education in study-abroad programs.

Who is the intended audience for students' writing? Should we be concerned with audience-awareness? Whereas audience-awareness has been recognized as a determining factor of the purpose of all writing (Lee 353) and is taught in all college writing courses, it has rarely been addressed in literature about students' overseas writing. None of the sources mentioned above discuss the issue of audience. By audience-awareness, I refer to one's means of shaping a piece of writing by anticipating responses from intended readers - readers with assumptions, attitudes, expectations, knowledge, and habits that may differ from one's own. As such, audience-awareness can be an effective way of communicating differences. If a writer is unaware of audience, as Douglas Park points out in "The Meaning of Audience," the writer's words, images, tone, and other linguistic features still imply the writer's subconscious assumption of audience (236). In study abroad, without audience-awareness, students' writing seems to imply a collective "us" as audience-students themselves or those who share the same home cultural habits and values-versus a collective "them," people in the host country. The actual readers of studyabroad writing have been instructors and classmates from the home country (Geloin 31; Vanouse 75). Such an audience raises the question of how effectively study-abroad writing serves as a means for students to learn about cultural differences and how to adjust to living in other cultures. To what extent does a culturally homogeneous audience encourage students to realize the relativity of their home culture and to understand the perspectives of host nationals? To what extent does such an audience encourage quality communication between our students and natives?

Born and educated in China and then in the United States, I am an experienced study-abroad learner and instructor. Examining the issue of 
audience in students' overseas writing from a cross-cultural perspective of both students and natives, I argue that overseas courses taught by home instructors do not have to be limited to students from home. We can design study-abroad writing to be intended for a native audience, and train students to explain feelings and thoughts in such ways that local readers can be empathetic about them. We can also create opportunities for students to discuss their writing with local people. Our students will thus increase their learning about cultural differences in ongoing, dialogic communication with natives, who, in turn, can learn about our students as individual Americans. If the goal of study abroad is to make students believe that knowledge is culturally bound (Kline 4), writing to a host audience is an effective way of putting students in the shoes of the host, by making students reflect on the culture of the host country and their own. My own experience as well as that of other instructors indicates that people in other countries truly appreciate opportunities to participate in collaborative learning with our students. I will also address how to prepare both host nationals and our students for using writing addressed to the former as a structure of cross-cultural collaborative learning in study abroad.

\section{An Analysis of Implied Home-Cultural Audience in Students' Writing}

In Writing Across Culture, Kenneth Wagner and Tony Magistrale recommend that overseas students use a journal to express and analyze their thoughts and feelings in their cross-cultural encounters (ix-xiv). Evidentially, journal writing has helped many of their students to develop empathy and tolerance, such as the well-documented case of the observant and comparative reflection of American and Swedish culture in the journals of one of their students, Sarah (Wagner and Magistrale 59-106). However, an implied home-cultural audience seems to have fostered students' perceptions centered on their home culture. Even the best journals, like Sarah's, occasionally reflect such perceptions. Moreover, such an implied audience does not encourage students to exchange feelings and thoughts with local people.

Many of our students stay with host nationals in close quarters, such as with a host family. Students' writing about their cross-cultural experience, however, implies a pull back from the local community to a com- 
munity of home-cultural readers, where local people are referred to in the third person: "they," "them," "my host brother," etc. This third person is not just a matter of pronoun reference. It facilitates a forum to comment about local people and culture behind the locals' backs. For instance, Andrea, a student in Sweden, writes, "Why don't they have normal salads, why don't they have chocolate chips?" (Wagner and Magistrale 9). "Can't this country afford to make better produce available?” asks Denise (10). Another student, Bill, writes two entries about social introductions. In the first one, he is surprised that he needs to introduce himself at a party: "Had I been to a party in the States, the host would have introduced me to everyone ... not so in Sweden" (10)! The second entry reads: "I am getting madder and madder at my host brother. He never introduces me to his friends. Last week, we met a friend of his on the subway and they talked as if I was not there. How rude” (15)! While Sarah reflects upon her frustration with such "little things" as "ethnocentricity," after her second arrival in Sweden (9), more than two months into the study-abroad program, she writes, "I simply cannot ignore those damn toilets" (85). Sikkema and Niyekawa's study includes similar complaints about daily matters from water to mailboxes (78-79).

Studying cultural differences on a home campus and abroad is dramatically different. In the latter situation, students' lives are directly affected and challenged. All the above students are disoriented in daily matters from food to social etiquette, and there is nothing wrong in expressing their feelings. Disorientation is a necessary component in overseas learning. However, does venting lead to learning? Must students bash natives to express themselves? The most important reason that students unfortunately do is that their writing is not intended for local people. Their writing implies an assumption that when it is read, without an explanation of "normal" salads and "better produce," readers will understand what the students mean. Students' home culture thus becomes the standard against which other cultural habits are measured. Bill, for example, is aware that the United States and Sweden do not have the same social customs, but he resents the fact that his host family follows a different custom, reacting as if his home-cultural custom were universal and preferred.

Study abroad offers an opportunity for students to learn about cultural differences via experience and how to communicate with people of 
different cultures. Current students' writing, however, records only fragmentary cultural dialogues between students and locals. I would like to turn to Sarah's writing, because it is composed over a period of several months. Sarah has learned from a conversation with a Swedish woman named Catarina that many Swedes may vote for the common good rather than for individual interests, contrary to what many Americans do. This conversation leads Sarah to speculate why Swedes like Catarina think so (Wagner and Magistrale 68). But Sarah does not seem to have pursued the issue by asking any natives why. The same lack of continued dialogue is true of her confusion about the Swedish society. Why would someone be class conscious in a society that seems to strive for social equality (75-76)? Why is there a noticeable absence of Swedish middle-aged or old people on the street (77)? Why do some Swedes value the environment (73)? Why do some Swedes wonder about the advantages of cable TV (86)? What do many Swedish women consider a beautiful hairstyle (88)? All these questions remain unaddressed and are mere questions of reflection. Similarly, in Bill's case, there is no communication of his feelings with his host family; his continuous writing only serves to increase his self-righteous anger.

The issue of home-cultural audience in study-abroad writing is not isolated. It seems as if, when we apply the concept of writing as a process of learning in study abroad, we have nonetheless followed perpetual patterns from the Anglo-European tradition of nonfiction travel writing: letters, diaries, logs, and memoirs. Despite differences in historical and literary conventions as well as individuality of travelers, one convention remains the same: that all travel writing has been intended for a home audience. As Steve Clark observes in a recent study on travel writing:

Something very strange has always happened in every travel narrative: the decision to be there, rather than here, and yet still wish to be heard here. The telling must be done on home ground, or at least a voice articulated within the home culture. Conversely, the native can thus never fully know the intruder, whose testimony becomes a kind of secret withbeld, a ritual of communal bonding achieved through this very act of exclusion. (17)

Let me give a few brief illustrations of Clark's point. In the late 4th century, a Roman pilgrim, Egeria, traveled to the holy land and wrote 
about the Biblical sites and church services. Her Travels is "the earliest surviving" record of personal traveling experience (Campbell 16). Addressed to her fellow nuns at home, who are familiar with the sites described in the Bible, Egeria only needs to refer to these sites as a witness. To quote, "a mile away on the river bank is the village where Holy Mary stayed with the Lord when she went to Egypt" (Egeria 94). "In Galilee is Shunem, the village of Abishag the Shunammite and of the woman in whose house Elisha stayed" (95). What about secular matters such as the population, housing, the food of the village, and the clothing the villagers wear? These matters are not of interest to Egeria the pilgrim nor her readers. In other words, although being in the Holy Land for three years offered Egeria an opportunity to learn about these other aspects of the local culture, Egeria's purpose and audience, as well as the fact that secular curiosity was regarded as a sin at this time (Stagl 48), channeled her learning.

In the contemporary age, homeward orientation still exists in many travel texts. Take, for example, Pico Iyer's The Lady and the Monk, a memoir of his 1980's stay in Kyoto. Sponsored by Time, Iyer sets his foot in Japan to interpret the country for a Western audience. Because to Iyer "Japanese public life [is] empty ritual and pageantry," knowing the real Japan must be done through a private relationship, as Traise Yamamoto critiques (333). Hence Iyer turns his Japanese lover, Sachiko, into a representative case study. Iyer hints to "us" (Iyer 261), those who are accustomed to a cultural ideal of individuality even in a married couple, that Japanese women like Sachiko are incomprehensible exactly because they efface their individual preference to please their men. When dining out, Sachiko will order the same dishes Iyer does, although it bothers her stomach (Iyer 260-61). What underlines Iyer's narrative is his identification with Western cultural values as opposed to non-Western values, represented by Sachiko (Yamamoto 329-30).

Another recent example is Peter Hessler's memoir, River Town: Two Years on the Yangtze, based on his experience as a Peace Corps English teacher at a college in Fuling City, Sichuan Province from 1996-1998. As Hessler says himself, he also collects material for his book (60). Often he writes or takes notes while taking a trip. But when his fellow Chinese travelers inquire about his writing, Hessler hedges, "'I am writing my foreign language.' That was enough to satisfy nearly everyone-If you 
know a foreign language, it was obvious that you would spend a great deal of time writing it. Nobody seemed to realize that in fact I was writing about them and everything else around me" (204-05). Episode after episode, Hessler shares with his Western readers, "the Chinese way" of doing things (390). This is the bond between a travel writer and homecultural readers Steve Clark refers to. It is a bond determining a writer 's choice of material, the angle from which to render the material, and the ways in which it is rendered.

\section{Why Address A Local Audience?}

It is fair to say that although journal writing is a way for students to express themselves and reflect on their experiences, we have not examined the point of view in students' writing. Writing to an implicit homogenous audience poses a dichotomist relationship between students and local people. Students like Bill tend to see his cultural values as superior and opposite to local values; hence their venting at the expense of local people. Is it possible for an outsider - a traveler, a study-abroad student- to write with a local audience in mind? What will be the purpose of doing so? In what ways is writing to a local audience a more effective way of learning than writing to a homogenous audience? The rest of this article will discuss the purpose, feasibility and preparation for students to share their writing with a local audience.

Asking students to write with an awareness of a local audience and making arrangements for them to discuss their writing with local people supports the ultimate purpose of study abroad. We have study abroad programs because we would like our students to understand via direct experience that people in different parts of the world do not have the same habits, customs, expressions and ways of thinking, and to develop sensitivity towards differences (Laubscher 88). Writing to a local audience will help students realize how our fundamental communication system, language itself, is culturally based. In an explication of the cultural theory of reading, Peter Smagorinsk argues that meaning is determined by its cultural context (135). Even people who speak the same language do not necessarily understand each other's message. John Platt cites the example of a Chinese "routine" greeting translated into English as "Have you eaten yet?"which a speaker of English, who does not know about the routine, 
may assume is a prelude to a meal invitation (19). The example represents a large pattern of "speakers who share, at least to some degree, the same language system but not, or at least not to the same degree, the same cultural system" (Platt 13).

Writing for a local audience will help students learn from cultural shocks without respect for the local culture. If local people can be arranged to discuss the writing with students, the writing will be instrumental in promoting focused and ongoing cultural dialogues. Instead of just being the subject of outsiders' learning, locals and our students will become learners about each other. As our students share their thoughts and feelings with local people, the latter will be likely to learn about the students as individual Americans. In these ways, students and local people engage in relationships, rather than perceiving each other as opposites. Only in these ways can students learn how to communicate differences with others.

Sikkema and Niyekawa define cultural shock as "the state of disorientation experienced by a person entering a new culture ... as he [or she] discovers for the first time that many of the things to which he [or she] is accustomed are unique to his [or her] own culture" (6). I would like to add that culture shock does not occur just in the beginning stage of students' cross-cultural experience, as if there would not be anything unexpected after a while. As they keep exploring the local culture, students are likely to come across unfamiliar situations. Furthermore, the fact that some students can overcome certain culture shocks does not mean that these shocks will not recur, as Wagner and Magistrale point out (85). Therefore, culture shock can occur at any point of students' overseas experience.

Sikkema and Niyekawa argue that culture shock itself is an important component of learning, because it functions as a wake-up call to cultural differences (43; also Whalen 2). However, cultural shocks do not necessarily lead to increased cultural tolerance and sensitivity (Talburt and Stewart 1). In fact, some students returned home earlier than expected because they were too homesick (Whalen 4). The cited journals speak to the degree of students' frustration. An important fact to keep in mind is that if students do not look at cultural differences from a cross-cultural point of view, they are not going to learn. Once they do, however, they are likely to keep an emotional distance from the cultural differences they experience, and learn what these differences mean to local people. My own experience in teaching study-abroad writing courses speaks to this fact. 
In the winter of 1999, while teaching Travel to Learn at Yavapai College, I took a class of 28 students, from 16 to 80 years of age, to the People's University in Beijing. The first night students arrived at the hotel of the University after a delayed trip of 25 hours, they found out that there was no hot water to take a shower. The hotel had hot water only a few hours a day. Instead of complaining about this inconvenience, Robert Widen wrote from the point of view of local people. Among a few other observations of an energy shortage, Widen says,

When we arrived at the hotel and discovered the 'bot water hours,' I knew China has a serious energy shortage. This immediately gave rise to an understanding of the importance, to China, of the Three Gorges Dam project on the Yangtze River, currently under construction... I I admire how the hotel saves energy. The key to the room turns on and shuts off electricity as one enters and leaves.

Lisa Willson's writing shows her perspective and explores that of natives:

One day, we went to a different part of the Great Wall called Gu Bei Kou Great Wall. I was in charge of the group. While I was trying to enjoy my climb a bustler caught up with me, telling me that he bad told our shuttle driver to pick us up at a different location. But if I gave him 20 Chinese yuan, he would make sure that the shuttle picked us up right at the foot of the Wall. I argued with him and said that I would pay him 20 yuan if and when he made sure that the shuttle picked us up on schedule and right where it should be. Finally the bustler went away. I was extremely mad.

But writing this episode from the point of view of local people has made me less angry, and I understand the whole situation better. I am thinking that China's privatization of the economy and its tourist industry have brought drastic changes to the villagers near the Great Wall. Prices are at least 10 times as high as they were a decade ago, while earnings have not matched up. How can a local peasant keep up with inflation? The appearance of foreign tourists certainly magnifies the gap between the rich and poor. We do have a lot of money comparatively speaking and we are easy targets. Twenty yuan is less than $\$ 3$ for us. 
Let us return to Bill's journals. Were students asked to address a local audience, common sense would have told them that saying: "You do not have normal salads, produce, breakfast, water, telephone system and toilets" is culturally insensitive. What is normal to an audience from home may not be normal to a local audience. Therefore, to communicate with local people, students must write about their cultural shocks in ways that make sense to the locals. For example, rather than getting angrier and angrier with his host brother, Bill could have written: "I am used to a culture where it is a common courtesy for family members to introduce guests of the family to the family's friends. I have realized that in Sweden a guest is expected to introduce him or her self or the guest will not be included in conversations. I am still struggling to get used to this custom."

When students write with a local audience in mind, they will reflect on their own cultural standards instead of reflexively using them to charge the locals. Thus, a change of audience does not diminish the role of students' memory of home in making sense of their new cultural experience. As Whalen argues, memory helps turn experience into learning if it functions as an effective comparison between the home culture and the new culture (9). When addressing a local audience, students can use their memory to explain why they feel in certain ways and learn how to express their own feelings without hurting those of others. If Bill shared the hypothetical journal entry with his host family, they might have explained to him Swedish customs and encouraged him to try them out. Such sharing does not have to be done in writing; verbal communication based on writing may be more congenial.

Addressing a local audience is also an efficient way of learning for short-term programs. Wagner and Magistrale's design of the analytical journal - in which, for the beginning period, the prominent period of cultural shock, students more or less just describe how they feel and then move on to analysis-may work only in the context of the traditional semester or year-long programs. Since 1990, when the Institute of International Education issued a mandate to diversify study-abroad programs to accommodate students who cannot afford a semester abroad for economic, family or other reasons, short-term programs such as programs for one or two months in the summer and during the winter break have been on the rise. To make the most efficient use of the short period of time, addressing a local audience will get students to analyze cultural dif- 
ferences from the beginning, as Lisa does.

Even though "extended, meaningful interactions" with host nationals enable students to gain significant insights into the host culture (Talburt and Stewart 1), many study-abroad instructors concur that "all but the most confident and outgoing students spend most of their leisure time moving in packs with other Americans" (Engle; O'Leary; Ward 232), not to mention that they are already "housed with other Americans and taught in courses set up just for them" (Engle). This manner of spending time resembles segregated tours, where "a community of language users in exile" stay in their safety net and observe the locals from a distance (Curtis and Pajaczkowska 207). They are "physically close but socially distanced from the native community" (Wang 148). American students are accustomed to studying with a syllabus. If we do not spell out policies to make sure they do their homework, many students probably will not do it or not do it well. Likewise, in study abroad, if we do not have an effective means of encouraging them to interact with host locals, many students probably will not make an effort of doing so.

Involving host nationals in the writing process facilitates dialogic learning between insiders and outsiders. In Tourism and Modernity, Ning Wang points out that "locals view their place of residence in a utilitarian and realistic manner" (161). They may not see the whole system because they are "acting within it" (Leed 62). Yet to travelers, what is to the locals "the ordinary, the usual, and paramount reality" can be "the extraordinary, the unusual, and paradise" (Wang 161). Because both outsiders' and insiders' perceptions are influenced by their respective historical and cultural conditions, exchanges of observation and interpretation of culture between outsiders and insiders prompted by writing to local people can open up horizons that are not possible with writing to a relatively homogeneous audience. A cross-cultural dialogue can offer "a chance ... to interrogate and negotiate, if not eliminate, both the traveler's cultural prejudices and those of the peoples he or she encounters" (Holland and Huggan 201).

My proposal for using writing to a local audience as a means of dialogic learning in study abroad is also supported by current literature on cross-cultural studies such as ethnography. In conventional ethnography, an outsider anthropologist presents the results of his or her participantobservation and interpretation of a culture to a home audience just as trav- 
el writers do. In recent decades, however, many ethnographers have realized the limitations as well as the power imbalance implied in conventional ethnography. Some have started to co-author with native experts (Clifford, Predicament 50-51). In Cross-Cultural Encounters: Face-to-Face Interaction, Richard Brislin discusses the value of locals' "commentary" on ethnographic works, including reasons why some locals may be "upset with some writings," how some ethnographic generalizations are based on "limited experiences" and "preconceived points of view," as well as in what ways ethnographic works "could be of help" to the locals (312-13). James Clifford believes that "with expanded communication and intercultural influence" (Predicament 22), a culture should be defined discursively, as "an open-ended, creative dialogue of subcultures, of insiders and outsiders, of diverse factions" (46). All these studies, from that of Ning Wang to James Clifford's, suggest that the soil is ripe for us to plant the seed of dialogic learning in study abroad via writing to host audiences.

\section{Can Participation of Local People in Study-Abroad Writing be Arranged?}

Significant as it is, having a local audience join the discussion of students' writing in study abroad may not be an easy task that leads to instant, across-the-board success. Differences in language, culture, institutional policies, communication styles, classroom cultures, teaching methodology, and political alliances all pose challenges. However, despite challenges, online writing to cross-cultural partners has already been a success. I have also had successful experiences arranging for local students to discuss issues with my students. Innovation and a flexible attitude is the key to success. It has been proven that writing to a cross-cultural audience can be done even when writers and readers are of different levels of English, different years of school, different class sizes and ages. More importantly, we do not have to wait for all conditions to be ready to ask students to address a cross-cultural audience. Just to imagine speaking to an audience outside of one's home culture is likely to make students empathize with a plethora of cultural behaviors and standards.

Helsinki University of Technology in Finland, Czech Technical University of Prague, and Indiana University in the United States experimented with a collaborative writing course via e-mail among students of 
the three universities in 1993. Students first got to know each other by discussing personal and academic topics. Then, in collaborative groups, they decided on paper topics according to common interests, conducted research on the topics, and eventually produced a paper (Kasikova 126). Instructors at all three universities guided and monitored the e-mail communication to ensure clarity of expression and academic quality (127). Although there was an uneven level of English proficiency among the students, the course produced benefits that a usual writing course on a U.S. campus will not. Students enriched their knowledge of other countries (133) by asking, in their own words, "real people about their opinions, ideas, feelings, customs" (129). In addition, cross-cultural partnership kept students excited, and they wrote far more than they would have in a regular writing course.

In 1989, 26 sophomores, ranging from 19 to 41 years of age, in an English class at Indiana University and Purdue University, and five comparative literature majors, ranging from 21-31 years of age, in a Master'slevel literature class at the University of Tampere in Finland shared an online drama-reading course. Students in each country had different writing assignments but had a common reading list (Schwartz 5). The American students wrote their interpretations in a regular journal and communicated them with their Finnish learning partners. All students commented that real cross-cultural partners helped them "understand what to include" in their writing and thus enhanced their communication skills in a global context (7). Students saw the relevance of their daily experiences in their interpretation and used them to explain to their crosscultural peers why they interpret texts in their own ways (6-8). Sometimes, though, cultural stereotypes surface in students' generalizations of their experiences. Yet most readers can detect these stereotypes and respond to them in a light-hearted manner (8). A survey at the end of the course indicates that the American students valued most the journal entries which provided their on-line exchange of interpretations.

In 1988, Manderley Grove Community School in London and Costa Mesa High School in California grouped students from both sides of the Atlantic into pairs to write on topics from personal names to Shakespeare's plays. There were risks and misunderstandings; but over the course of a year, students felt comfortable and confident in revealing themselves to their cross-cultural peers (Freedman 187). Teachers from both schools 
played a major role in ensuring the success of this writing project. They were sensitive and knowledgeable enough of the different classroom cultures and educational methods to explain to their respective students, for instance, why they received the kinds of peer responses they did (118-19). All three projects indicate that cross-cultural audience awareness motivates students to take their writing more seriously than they would have in monoculturally-based courses (Kasikova 129), and to sort out "culturally-bound" perspectives (Freedman 1).

If these online cross-cultural collaborative courses can be successful, we can also make successful collaboration in writing to host nationals in study abroad. At the present time, most study-abroad programs are in "English-speaking countries" (Goodman), but the trend is turning to nonAnglo-European countries (Desruisseaux). Writing to a local audience certainly is not limited to native English speakers. As we have seen, students of English as a second language in Finland and the Czech Republic could communicate well with U.S. students. English is also spoken as a second language in many Asian and African countries. In China, for example, a foreign language is often a required subject starting in grade school (Cheng 162). Yet these countries often face the challenge of limited resources for learning a second language. Therefore, many college teachers in these counties value the opportunity for their students of English to interact with native speakers; this was the incentive for Czech Technical University of Prague to have been involved in the online cross-cultural writing course (Kasikova 125).

In 1999, I managed to experiment with a joint discussion of crosscultural views between my students from Yavapai College and a group of 20 students from the Chinese Literature Department of the People's University in Beijing. For most of the meeting, students chatted about their backgrounds, motives for being university students, career goals, dating opportunities, and leisure activities in a relaxed and friendly atmosphere. The year 1999 was also a time when the issue of freeing Tibet comprised much of the talk in the U.S. media. Not surprisingly, one of my students asked why China did not free Tibet. Immediately, many people in the room felt tense. A few Chinese students explained their views and one raised the question of why now and then the United States sends troops to other countries to engage in war, and whether the U.S. people can stop the government from sending out the troops if they do not like 
the participation in war. The answers from my students led to a Chinese student's further inquiry on how democracy works in the U.S. My students were firing their different answers across the room. I made a comment at this point to this cross-cultural student body: "See, this is democracy in action," and everyone laughed. Despite tension and disagreement, our meeting ended with students breaking into smaller groups trying to get to know each other and exchanging good wishes. In their journals and essays, my students valued this meeting the most. Not only did they learn some Chinese perspectives, but also they respected the Chinese students for openly discussing even sensitive issues with them.

In March 2001, from Embry-Riddle Aeronautical University (ERAU), I organized an optional field trip for my travel literature class to Beijing University of Aeronautics and Astronautics (BUAA). Because of schedule conflicts and time constraints, we were not able to hold classroom meetings with students from both universities. Yet a mutual determination of both universities to facilitate quality interaction between students led to our experiment of using our shuttle bus as a mobile classroom. On a daily basis, four BUAA students of English would hop on the shuttle with 12 students of mine to places of interest. My students would discuss issues in their journals such as pollution, the legacy of Mao, and dating in college with BUAA students, who appreciated so much this rare opportunity of practicing and learning English, if not American culture. When students from both universities visited the same sites, such as the Tomb of Mao Ze Dong, they would discuss what the visit meant to them, and had an on-the-spot experience of cross-cultural interpretations. Such close and extended interaction resulted in the budding of lasting friendships, despite, not surprisingly, disagreements on certain issues. Even so, our departure day was hard for students from both universities

Based on the enthusiastic responses from students and faculty of both universities, our two institutions have planned an intensive collaborative class over six weeks on the campus of BUAA in the summer of 2002, pending sufficient enrollment. The course is called Contemporary China. My students will be: reading a textbook on the changes in Chinese society since it opened its door in the late 1970's; going on organized excursions to companies, schools, factories, and individual homes, as well as to places students themselves decide helpful to their understanding of China; and writing journals and essays about their out-of-classroom expe- 
rience with an intended audience of BUAA peers. Three times a week, BUAA students of English will take turns to join the class, offer peer response to my students' writing, answer their questions, and help my students decide where to go and/or who to interview in order to develop their understanding.

Because of different institutional policies as well as linguistic and cultural differences, collaborative classes may not always be feasible. Even in such situations, we can consider involving "a representative of [the locall audience in the writing process," as Lisa Ede and Andrea Lunsford suggest (89), through inviting him or her to class discussion or giving students' journals by turns to the representative. This representative reading is similar in a way to how "we ask a colleague to read an article intended for scholarly publication" (89).

\section{Preparing for Collaboration in Writing to Host Nationals}

To ensure the success of writing to a local audience as a structure of collaborative learning in study abroad, partners at home and abroad need to be well prepared, as Annette Scheunpflug recommends for all types of cross-cultural learning (113). In addition to foreign language and cultural knowledge, the most important element of preparation is that both partners understand how writing to a local audience works in collaboration, and the role each partner plays in the learning process. The purpose of such preparation is to make students take charge of the learning process, and become self-motivated learners. For many institutions, this process-oriented preparation has resulted in semester-long pre-departure courses, as reflected in Sikkema and Niyekawa's work and Brian Whalen's emphasis on the importance of teaching students the learning process (Whalen, 10-13).

Part of the cultural knowledge should consist of communication styles of each culture. Communication experts argue that countries such as China and Spain are "associative cultures," in which meaning is largely derived from associations rather than cause and effect as in "abstractive cultures," like the United States and France (Korac-Kakabadse 8-9). In associative cultures, communication tends to be "indirect and implicit," whereas in abstractive cultures, communication tends to be the opposite (9). Understanding this general pattern of communication styles will help 
cross-cultural learning partners decide how to explain themselves and when to ask questions.

To avoid hasty generalizations, both learning partners need to know how people tend to perceive each other in cross-cultural situations. Dennison Nash states that in cross-cultural contact, visitors and locals tend to conceive each other not "as individuals, but as strangers of a particular type" (44-45), as representatives of each other's culture (37). In a study of "Participants' Perspectives," Wilkinson also notes that American students tend to distinguish themselves as individuals on home campuses. Abroad, however, they group themselves as Americans (32). This is so, Eric Leed explains, because one finds one's affiliation with one's own type as one identifies strangers as their own type, a "defense against the strange and unusual" (68). Regular discussions and interactions between people of different cultures should reduce this tendency of generalization, as they get to know each other more and more as individuals. Since to predict and adapt to the audience are "two of the basic principles of human communication" (Samovar 67), we should have cross-cultural learning partners get to know each other and discover common interests via e-mail prior to departure, as in the case of the successful first stage of writing in the triinstitutional, tri-national online writing course in Kasikova's article (126). In the case of my summer collaborative learning course, our partners at BUAA will read and discuss sample journals and essays of my students before our arrival.

At Embry-Riddle Aeronautical University, I created and have been teaching a study-abroad preparation course titled "Observation in Asian Cultures." The purpose of the course is to help students understand the history and complexities of learning abroad, how to use writing to structure learning overseas, how writing to host nationals can significantly enhance the learning, and the general methodologies of ethnography. There are four parts to this course. The first part is an overarching study of cross-cultural contact and research. James Clifford 's "Introduction to Writing Culture"(1-26) and Mary Louis Pratt's "Field Work and Travel Writing" (27-50) are the primary texts. Although students in the class are neither anthropology majors nor professional travel writers, they can see that study abroad involves the same ethnological method of participant observation, the same need of collaborative interpretation of culture, the dialectical relationship between the observer and observed, and, very 
importantly, the observation of changes in oneself as one gains knowledge about other cultures.

Part Two is a survey of Anglo-European travel writing about Asia, including excerpts from such texts as Egeria's Travels (122-23), Marco Polo's Travels (163-65), Anathasius Kircher's China Illustrata (192-94), and Lady Mary Montague's Turkish Letters (90-92). Through the reading and discussion of these excerpts, my students have learned how travelers' writing is influenced by the milieu in which the travelers live, as well as such factors as gender, occupation, and the purpose of their travel and writing. Students also learn to see how modern anthropology evolves from travel writing. Knowledge from this survey lays a foundation for students to critique their perspectives in study-abroad writing.

Following this survey is the third and central part of the course, using two contemporary travel texts: Peter Hessler's River Town and Pico Iyer's The Lady and the Monk. These two texts are chosen because our university's Asian Studies program centers on East Asia and our study abroad program is in China. Students are asked to analyze an individual traveler's process of learning, how a traveler deals with daily challenges, how a traveler observes and makes sense of his or her encounters in another culture, the degree and manner of interaction between the traveler and the locals, cultural and gender stereotypes, and implied audience. This analysis takes students vicariously through processes of learning abroad.

The last part of the course is the practice of writing to host nationals. The class members discuss sample writing from previous study-abroad students; they also practice writing to different audiences, including exploring the degree to which one needs to explain oneself, effective wording, and alternative ways of organizing a piece of writing, as recommended by Ede and Lunsford (91) and Icy Lee (353). As a result of such a preparatory course, students will be able to understand study abroad from a historical, methodological aspect, in-depth case studies, and hands-on practice. They will have cultivated serious and realistic attitudes towards study abroad, self-reflective habits, and a readiness as well as willingness to use writing as a means of communication with their hosts and overseas peers with whom they already will have established a relationship.

Good preparation provides the foundation on which to start the process of writing to host nationals on site. In the process, we need to continue to guide students to specify the local audience as they come to know 
the hosts more and more. Cultural sensitivity can never be overstressed; this includes: making efforts at legible handwriting when computers and typewriters are not available, slower pace of speech, and listening with patience and intensity (Samovar 117). As expected, exchanging views in a cross-cultural environment is likely to bring about disagreement and conflicts (Freedman 118-19). Although my students did not take disagreements personally, there is always the possibility that they may. To help keep up students' self-esteem, we need to make sure that collaborative discussion is done supportively and constructively.

John Marcum, director of the University of California Education Abroad Program, believes that the future of U.S. study-abroad programs should be "characterized essentially by collaborative engagement with other countries," rather than by a more imperial projection of American interest" (B8). Through our efforts of creating cross-cultural collaborative learning via students' writing to a local audience, future U.S. students abroad can become participants in ongoing, mutual-learning dialogues. They will form a new generation of global citizens.

\section{References}

Altschuler, Glenn. "La Dolce Semester: Studying Abroad is Most Students' Favorite College Experience. But Not Necessarily for the Right Reasons." The New York Times 8 April 2001, sec. 4A: 17.

Brislin, Richard. Cross-Cultural Encounters: Face-to-Face Interaction. New York: Pergamon, 1981.

Campell, Mary. The Witness and the Other World: Exotic European Travel Writing, 400-1600. Ithaca: Cornell University Press, 1988.

Cheng, Chin-Chuan. "Chinese Varieties of English." In The Other Tongue: English across Cultures. Ed. Braj Kachru. 2nd ed. Urbana: University of Illinois Press, 1992. 162-77.

Clark, Steve. "Introduction." Travel Writing and Empire: Postcolonial Theory in Transit. Ed. Steve Clark. London: Zed Books, 1999. 1-28.

Clifford, James. "Introduction." Writing Culture: The Poetics and Politics of Ethnography. Eds. James Clifford and George Marcus. Berkeley: University of California Press, 1986. 1-26.

... The Predicament of Culture: Twentieth-Century Literature, Ethnography and Art. Cambridge: Harvard University Press, 1988. 
Curtis, Barry and Claire Pajaczkowska. “'Getting there': travel, time and narrative." Travelers' Tales: Narratives of Home and Displacement. Eds. George Robertson, et al. New York: Routledge, 1994. 199-215.

Desruisseaux, Paul. "Fifteen Percent Rise in American Students Abroad Shows Popularity of Non-European Destinations." Chronicle of Higher Education 10 Dec. 1999: A60.

Ede, Lisa and Andrea Lunsford. "Audience Addressed/Audience Invoked: The Role of Audience in Composition Theory and Pedagogy." CROSS-TALK IN COMP THEORY: A Reader. Ed. Victor Villanueva. Urbana: National Council of Teachers of English, 1997. 77-95.

Engle, John. "Creating More Rigorous and More Appropriate StudyAbroad Programs." Chronicle of Higher Education 17 Mar. 1995: A56.

Freedman, Sarah Warshauer. Exchanging Writing, Exchanging Cultures: Lessons in School Reform from the United States and Great Britain. Cambridge: Harvard University Press, 1994.

Geloin, Chislaine. "Avoiding a U.S. Curriculum Transplant Abroad: The Ethnographic Project." Innovative Approaches to Curriculum Design in the Study Abroad Program. Ed. Deborah Hill. Columbus: Renaissance, 1987. 23-34.

Goodman, Allan. "America Is Devaluing International Exchanges for Students and Scholars." Chronicle of Higher Education 12 Mar. 1999: A56.

Hessler, Peter. River Town: Two Years on the Yangtze. New York: HarperCollins, 2001.

Holland, Patrick and Graham Huggan. Tourists with Typewriters: Critical Reflections on Contemporary Travel Writing. Ann Arbor: University of Michigan Press, 2000.

Iyer, Pico. The Lady and the Monk: Four Seasons in Kyoto. New York: Vintage Books, 1992.

Kasikova, Stanislava. "Creating an International classroom through email." Effective Teaching and Learning of Writing: Current Trends in Research. Eds. Gert Rijilaarsdam, Huub van den Bergh, and Michel Couzijn. Amsterdam: Amsterdam University Press, 1996. 124-35.

Kircher, Athanasius. China Illustrata. Trans. from the 1677 Latin edition by Charles Van Tuyl. Bloomington: Indiana University Press, 1987. Kline, Michael. "Study Abroad and the Liberal Arts: The Canon in Disarray." Innovative Approaches to Curriculum Design in the Study Abroad 
Program. 1-14.

Korac-Kakabadse, Nada, et al. "Low-and High-Context Communication

Patterns: Towards Mapping Cross-Cultural Encounters." Cross Cultural Management 8 (2001): 3-24.

Laubscher, Michael. Encounters with Difference: Student Perceptions of the Role of Out-of-Class Experience. Westport: Greenwood, 1994.

Lee, Icy. "Exploring Reading-Writing Connections through a Pedagogical

Focus on 'Coherence.' " Canadian Modern Language Review 57 (2000): 352-6.

Leed, Eric. The Mind of the Traveler: From Gilgamesh to Global Tourism. New York: Basic Books, 1991.

Marcum, John. "Eliminate the Roadblocks." The Chronicle of Higher Education 18 May 2001: B7-9.

Montagu, Lady Mary Wortley. Selected Letters. Ed. Robert Halsband. London: Penguin Books, 1986.

Nash, Dennison. "Tourism as a Form of Imperialism." Hosts and Guests. Ed. Valene Smith. Philadelphia: University of Pennsylvania Press, 1989. 37-54.

O'Leary, Michael. Letter. Chronicle of Higher Education 12 May 1995: B4.

Park, Douglas. "The Meaning of Audience." The Writing Teacher's Sourcebook. Eds. Gary Tate, Edward Corbett and Nancy Myers. 3rd ed. Oxford: Oxford University Press, 1994. 233-42.

Platt, John. "Some types of communicative strategies across cultures: Sense and sensitivity." English across Cultures. 13-29.

Polo, Marco. The Travels. Trans. and intro. by Ronald Latham. Penguin Classics, 1972.

Pratt, Mary Louise. "Fieldwork in Common Places." Writing Culture: The Poetics and Politics of Ethnography. Eds. James Clifford and George Marcus. Berkeley: University of California Press, 1986. 27-50.

Samovar, Larry. Oral Communication: Speaking Across Cultures. 11th ed. Los Angeles: Roxbury, 2000.

Scheunpflug, Annette. "Cross-Cultural Encounters As a Way of Overcoming Xenophobia." International Review of Education 43.1 (1997): 109-16.

Schindler, Roslyn, et al. "The Classroom Abroad: Interdisciplinary CrossCultural Perspectives for the Adult Learner." Innovative Approaches to Curriculum Design in the Study Abroad Program. 104-112. 
Schwartz, Helen. "Cross-Cultural Team Teaching: E-mail for Literary Analysis." Fiche: ED 319060.

Sikkema, Mildred and Agnes Niyekawa. Design for Cross-Cultural Learning. Yarmouth, ME: Intercultural Press, 1987.

Smagorinsky, Peter. "If Meaning is Constructed, What is it Made from? Toward a Cultural Theory of Reading." Review of Educational Research 71 (2001): 133-39.

Stagl, Justin. A History of Curiosity: The Theory of Travel 1550-1800. Chur: Harwood, 1995.

Strevens, Peter. "English as an International Language: Directions in the 1990s." The Other Tongue. Ed. Braj Kachru. Urbana: U of Illionis P, 1982. 1992 Rpt.

Talburt, Susan and Melissa Stewart. "What's the Subject of Study Abroad?: Race, Gender, and 'Living Culture'." The Modern Language Journal 83 (1999): 163-75.

Vanouse, Donald. “American Readers and Writers in England.” Innovative Approaches to Curriculum Design in the Study Abroad Program. 74-82.

Wagner, Kenneth and Tony Magistrale. Writing Across Culture: An Introduction to Study Abroad and the Writing Process. New York: Peter Lang, 1995.

Wang, Ning. Tourism and Modernity: A Sociological Analysis. Amsterdam: Pergamon, 2000.

Ward, Martha. "Managing Student Cultural Shock: A Case from European Tirol." Antbropology and Education Quarterly 30.2 (1999): 228-37.

Whalen, Brian. "Learning Outside the Home Culture: An Anatomy and Ecology of Memory." Frontiers: The Interdisciplinary Journal of Study Abroad 2 (1996). <http://www.frontiersjournal.com /back/two/l.html.> 1-22.

Wilkinson, John, ed. and trans. Egeria's Travels. 3rd. ed. Warminster: Aris and Phillips, 1999.

Yamamoto, Traise. “ 'As Natural as the Partnership of Sun and Moon': The Logic of Sexualized Metonymy in Pictures from the Water Trade and The Lady and the Monk." Positions: East Asia Cultures Critique 4:2 (1996): 321-41. 